\title{
Preface
}

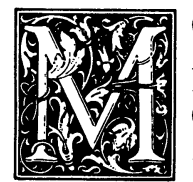

ORE THAN forty years of practicing forestry in the South provided a lot of experiences that I wanted to pass along. Others encouraged me to do so. Before I came to work in and to study the southern woods, explorers, pioneers, and lumbermen had quite literally left their marks on the region. Understanding the significance of those blazes in the forest appeared to me to be essential to appropriately manage the woodlands today and to suggest trends for the future husbanding of these renewable natural resources.

The experiences of one person's career, of course, tell but a little of what has occurred during that period. It is but a sample; and as foresters deal daily with sampling theory, I am well aware of the limitations. So it is that I am indebted to hundreds of fellow foresters, woodusing industrialists, academic colleagues, and former students who, over the years, have contributed to my grasp of Dixie's lands and people. We have labored together in the woods, at the laboratory bench, in the statistical analysis room, and around the seminar table. Always the interest of these friends has been altruistic, always to prepare for the laborers who must follow, always to provide wood and wooded landscapes for future citizens of the South to utilize or to enjoy. I shall forever be grateful to these fellow sojourners - the contributions of many of them no doubt unknown to themselves-who have guided me along the way. I recall their words, their example, and their occasional disagreements with me that have enlivened my career as a professional forester.

My career has brought no regrets, spanning as it has the dramatic rise of the forestry profession immediately following the Second World War to the present reduction in the roster of foresters. The decline, so prevalent as I write, relates to the difficulties now experienced in 
the timber industry for which many serve as journeymen and to budget trimming by governments that employ many more.

Chapters I through 5 deal principally with history, but it is not "pure" history. The author's personal experiences and his own interpretation and speculation about the significance of events occurring in particular periods have been intentionally woven into the text's fabric. The final chapter, 6 , is not solely a collection of the writer's predictions. Many ideas came about through participating in foresters' never-ending informal group discussions, listening to formal presentations, and reading contemporary material as well as from gut feelings. Thus, these lines are not the story of the southern forest; they are one story that I hope will be helpful to readers within and outside of the forestry profession.

Some colleagues deserve especial mention for a list of reasons too long to elaborate: John E. Johnson, Ivan J. Nicholas, Ab Smith, Thomas Croker, and Dr. William Campbell, all of the U.S. Forest Service; Professor Donald P. White, Dean Hardy Shirley, and the late Dean Svend O. Heiberg of the New York State College of Forestry; Professor Harold J. Lutz and Professor David M. Smith of Yale University; and Donald Young of the Texas Forest Service. I express my appreciation too to my fellow faculty members over the years at Stephen F. Austin State University (SFASU) for encouraging me to tell this story.

Chapters of this volume have been critiqued by Bruce Miles, Dr. Hans van Buijtenen, Edwin Barron, and Donald Young, all of the Texas Forest Service; James Webster of the Kirby Lumber Company; Ron Hufford, Texas Forestry Association; Roger Dennington, U.S. Forest Service; and Macky McClung, Kathryn Duncan, James Meeker, James Mitchell, and Stephen Rockwood, graduate students at SFASU. Dr. Robert Maxwell, my colleague and late Regents' Professor of History and Adjunct Professor of Forest History at SFASU, reviewed the entire manuscript. Although these others assisted me, please fault me alone for any errors.

I thank Jamie Taylor, Michele Allen, Melinda Escude, Sheila Wilhite, and Stacy Shaw, typists who patiently and pleasantly transcribed the scribbles of an arthritic hand. Dr. Kent T. Adair, my successor as dean of the School of Forestry at Stephen F. Austin State University, encouraged this endeavor. And to Beth W. Allen, editor extraordinary, my grateful thanks for patient attention to detail.

L.C.W.

Nacogdoches, Texas 


\section{THE SOUTHERN FOREST}


